\title{
Christianity and epilepsy
}

\section{Chrześcijaństwo i padaczka}

\author{
Krzysztof Owczarek', Joanna Jędrzejzzak² \\ IDepartment of Medical Psychology, Medical University, Warsaw, Poland \\ 2Department of Neurology and Epileptology, Medical Centre for Postgraduate Education, Warsaw, Poland
}

Neurologia i Neurochirurgia Polska 2013; 47, 3: 271-277

DOI: 10.5114/ninp.2013.35485

\begin{abstract}
Epileptic seizures have been known from time immemorial. Throughout the ages, however, ideas concerning the aetiology and treatment of epilepsy have changed considerably. Epilepsy is mentioned many times in the Pentateuch, where it is portrayed as a mysterious condition, whose symptoms, course and contingencies evade rational laws and explanations. In the Middle Ages, the accepted view which prevailed in social consciousness was that patients with epilepsy were possessed by Satan and other impure spirits. One common method of treatment of epileptic seizures was to submit the patient to cruel exorcisms. Patients were frequently injured in the process and some of them even died. Our understanding of epilepsy and its social consequences has improved considerably within the last century. The most significant progress as far as diagnosis and treatment of epilepsy is concerned took place in the last four decades of the twentieth century. Although we now know much more about epilepsy than we used to, this knowledge is still insufficiently popularized.
\end{abstract}

Key words: epilepsy, historical aspects of epilepsy, stigma, psychosocial factors.

\section{Introduction}

Humanity has been troubled by epilepsy since time immemorial and from time immemorial people have

\section{Streszczenie}

Napady padaczkowe są znane od najdawniejszych czasów. Wraz z upływem wieków poglądy na temat pochodzenia i leczenia padaczki znacznie się zmieniały. W Pięcioksięgu padaczka pojawia się wielokrotnie jako choroba tajemnicza, której postać, przebieg napadów oraz okoliczności występowania nie poddawały się racjonalnym regułom i wyjaśnieniom. W średniowieczu dość powszechnie w świadomości społecznej osoby z padaczka jawiły się jako nawiedzone, opętane przez szatana i inne siły nieczyste. Jedną z powszechniej stosowanych metod powstrzymania napadów padaczkowych było poddawanie chorych okrutnym egzorcyzmom. W trakcie tych dotkliwych procedur osoby z padaczką często okaleczano, czasami takie zabiegi kończyły się wręcz utratą życia. W minionym stuleciu znacznie poszerzył się zakres wiedzy związanej z występowaniem padaczki i jej społecznych skutków. Najistotniejsze zmiany dotyczace rozpoznawania i leczenia padaczki nastąpiły w ostatnich czterech dekadach XX w. Mimo że na przestrzeni lat wiedza o padaczce bardzo się zwiększyła, to jest ona nadal w niewystarczającym stopniu spopularyzowana.

Słowa kluczowe: padaczka, historyczne aspekty padaczki, stygmatyzacja, czynniki psychospołeczne.

striven to identify its causes. Ideas concerning treatment of people with epilepsy have likewise evolved, gradually but systematically. Mention of the aetiology of epilepsy, its symptoms, methods of prevention and treatment

Correspondence address: prof. Krzysztof Owczarek, Zakład Psychologii Medycznej, Warszawski Uniwersytet Medyczny, ul. Żwirki i Wigury 81 A, 02-091 Warszawa, e-mail: krzysztof.owczarek@wum.edu.pl

Received: 7.07.2012; accepted: 2.11.2012 
can be found in many ancient civilizations. Ancient written sources can generally be divided into two groups: philosophical-medical and religious. The first group is represented in antiquity and the middle ages by Hippocrates, Aristotle, Galen, Averroes, and Avicenna [1]. Religious sources, on the other hand, have referred to and reflected the knowledge accumulated in philosophical-medical sources to a greater or lesser extent. When one studies the literature on epilepsy from bygone times one often finds signs of superstition and prejudice regarding epilepsy and people afflicted with this disease. Attitudes toward people with epilepsy were often the litmus test of the level of social mores and civilization.

Wolf [2] quotes many interesting interpretations of phenomena relating to the cultural aspects of epilepsy from a historical perspective. He argues that the way people with epilepsy are treated depends on the direction and level of development of the broadly understood cultural norms of contemporary society. He discusses the effects of religion and superstition on the contemporary family, its mobility, employment opportunities, and legislation concerning people with epilepsy vis-à-vis various ancient historical events. Religion had a major impact on people's mentality in many countries. Even today in some countries the truths of faith continue to play a significant role due to their public presence. Baker and collaborators [3] studied attitudes toward epilepsy in several European countries and found that they varied considerably. The studied societies differed significantly with respect to the intensity of negative, stigmatizing attitudes toward epilepsy. It is surely no coincidence that Poland, Spain and Portugal were among the most tolerant countries whereas France, Germany and Great Britain were among the most stigmatizing ones.

This shows that the extent to which one will be stigmatized partly depends on where one lives. It is therefore highly probable that attitudes toward epilepsy depend on the normative system which prevails in a given society (its law, mores, traditions, etc.). In other words, we should look for the causes of social prejudice and prejudiced behaviour toward people with epilepsy in social customs - what prevails and what is lacking in these customs. Of course it is not easy, even empirically, to determine the extent to which religion, tradition, rituals, mores, etc. shape people's attitudes. Besides, contemporary social norms are largely determined by former or current religious beliefs. What we can do, however, is try to identify the contents of the most important religious writings which have shaped the evolution of the most important cultural norms in specific regions, societies or countries.

\section{The Old Testament}

In the Old Testament, all diseases were thought to be punishments for the sins of individuals or entire societies and warnings not to violate God's laws. This is also true of epilepsy although in the original text it is called the 'falling sickness'. Jahve allegedly inflicted epileptic seizures on people and only he could alleviate their suffering. In chapter 21 of the First Book of Samuel we have the story of young David escaping from Saul to the Philistines. In order to avoid being taken hostage, he simulates epileptic seizures whose symptomatology resembles tonic-clonic attacks. 'So he pretended to be insane in their presence; and while he was in their hands he acted like a madman, making marks on the doors of the gate and letting saliva run down his beard' [I Sam 21:13]. This is probably the oldest account of a pseudoepileptic seizure.

Where there are pseudo-epileptic seizures, there must also be models to be emulated. We need not look far. In the same book we find an account of the peculiar behaviour of Saul, the king of Israel, who undressed then fell to the ground and lay there all day and all night. This behaviour reminds us of an epileptic state, probably preceded by a psychomotor seizure. These seizures were God's punishments for Saul's vile acts and disobedience. Saul repeatedly threatened to kill David, who was designated to be the next king of Israel.

In Book IV of the Pentateuch we find the story of Balaam of the Midianites. Balaam announced the coming of the Holy Spirit. He saw this truth in his soul's eye when, having been struck to the ground, he understood the will of the Almighty. Inscriptions discovered in the middle valley of the river Jordan and dated 750 $\mathrm{BC}$ are testimony of the activities of Balaam, son of Beor, in the days of the Middle Kingdom. Famous for his talents, he was summoned by Balak, king of the Moabites, who promised to pay him well if he cursed the Israelites who settled in Moab after fleeing from Egypt. Balaam made three sacrifices to God in the presence of Balak, the donor, and Jahve blessed the Israelites three times, angering the king greatly. We read in the Bible that Balaam fell to the ground during the blessing. The ancient Hebrew term for this falling is nophel, the same one that is used to describe Saul's attacks. Obviously this word conveys the activity of a spirit, be it God's spirit or an impure spirit. When we analyse the accounts of Saul, David and Balaam, we find testimony of faith in the inevitable bad prognosis for patients, their inferiority, and interpretation of epileptic seizures in terms of God's 
punishment for bad deeds. This faith was very common in ancient times and is still quite common today.

In the Pentateuch, epilepsy is mentioned repeatedly and is portrayed as a mysterious disease whose manifestations, seizure dynamics and contingencies of occurrence did not fit rational patterns and explanations. According to the injunctions of Talmudic law, slaves were sold with a 100-day warranty period, just in case they were found to be epileptic. The common Judaist belief was that epileptic seizures were hereditary and so it was forbidden to marry a woman with a history of epilepsy in the family. An epileptic woman's inferior social position was an additional reason for not marrying her. Legal marriage could be annulled if it was later found that the woman had epilepsy. Epileptic men were forbidden to be priests, rabbis or judges. On the other hand, priests and rabbis were categorically forbidden to treat people with epilepsy for fear of becoming contaminated [4].

\section{The Catholic Religion}

The New Testament contains many fewer themes associated with epilepsy. To this day the jury is still out on whether the famous conversion of St Paul on his way to Damascus had epileptic origins: was this biblical episode not preceded perhaps by partial visual seizures?

On the other hand, the Gospel according to St Luke [5] contains an account of a case where Jesus cured a man who was in the possession of demons, a patient with epilepsy. Here is what the Gospel says: "The next day, when they came down from the mountain, a large crowd met him. A man in the crowd called out, 'Teacher, I beg you to look at my son, for he is my only child. A spirit seizes him and he suddenly screams; it throws him into convulsions so that he foams at the mouth. It scarcely ever leaves him. I begged your disciples to drive it out, but they could not.' 'You unbelieving and perverse generation,' Jesus replied, 'how long shall I stay with you and put up with you? Bring your son here.' Even while the boy was coming, the demon threw him to the ground in a convulsion. But Jesus rebuked the impure spirit, healed the boy and gave him back to his father" [Luke 9: 37-42].

Since the dawn of Catholicism, the faithful who sinned against God were submitted to "inquisition" (investigation, enquiry). For penance they were usually told to pray or go on a pilgrimage. It was only Pope Innocent III (1198-1216) who, in an attempt to curtail the activities of sects and heretics, turned the institution of inquisition into an apparatus of brutal terror. He rendered the monks who were involved in the battle with heresy responsible only to God's Throne for their methods of enquiry and the punishments they adjudicated.

In the Middle Ages, Christians widely believed that persons with epilepsy were possessed by demons and other impure forces. One example of those murky times and prevalent opinions and customs concerning the lame and the sick was the Dominican handbook whose full title is Malleus Maleficarum - maleficas \& earum haeresim ut phramae potentisima conteresu [The hammer of witches that destroys witches and their heresy like a most powerful spear] [6] (Fig. 1). This book was written by two inquisitors designated by Pope Innocent VIII and sent to south Germany to cleanse the territory from heretics and persons practising Satanism. Here is a quotation from the book: 'But were I to wish to mention everything which happened in this little town, it would fill quite a large book. There were very many blind, lame, shrivelled people, and people tormented by various diseases, who gave legal testimony that witches had made them ill, for either a short time, or mortally. Also, that all this had happened according to the tales and threats of witches, whether in some illness, or some other mor-

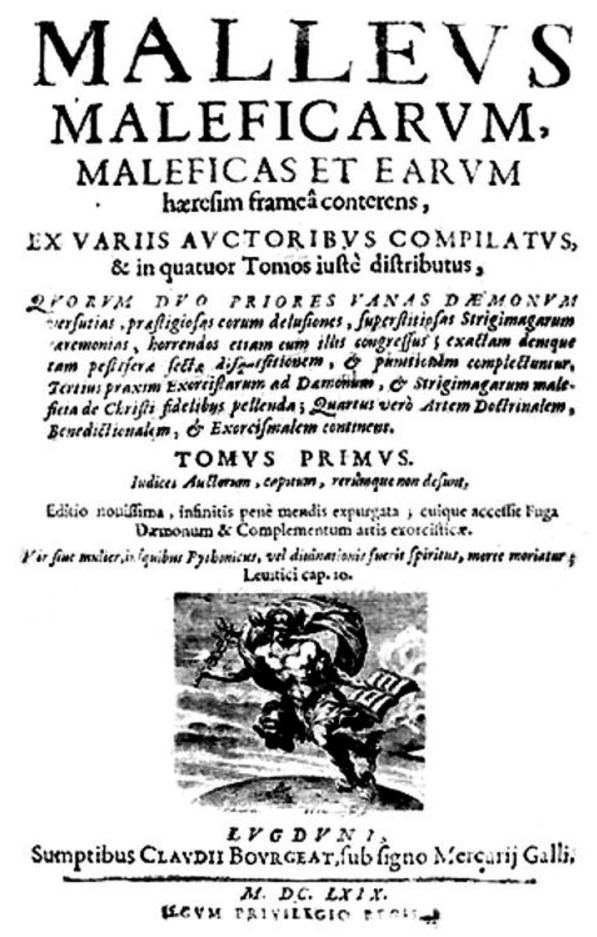

Fig. 1. Sprenger \& Institor, "Malleus Maleficarum", Lyon 1669 (http://zwojescrolls.com) 
tality'. And another quotation which explicitly mentions epilepsy: 'There is no bodily illness which the witches, with God's permission, were incapable of inflicting, be it leprosy, or epilepsy, or some other major malady, there can be no doubt about it'. Basically, one of the more popular methods used to stop epileptic attacks was to submit patients to elaborate and cruel exorcisms. During these painful procedures epileptic patients were often injured and sometimes the treatment led to loss of life. Also, it was not difficult to be accused of witchcraft or black magic. What was much more difficult, however, was to deny such practices during these elaborate and cruel tortures (Fig. 2). The first trial to which the suspect (usually female) was submitted was the trial of water. The suspect was thrown into the river to see whether she would drown. If she did not, this meant that evil forces kept her afloat. If she drowned in the depths of the river, this meant that she had been prematurely and unjustly accused. Many centuries had to pass before the enlightenment dispersed the darkness of superstition, prejudice and stigma engulfing people with epilepsy.

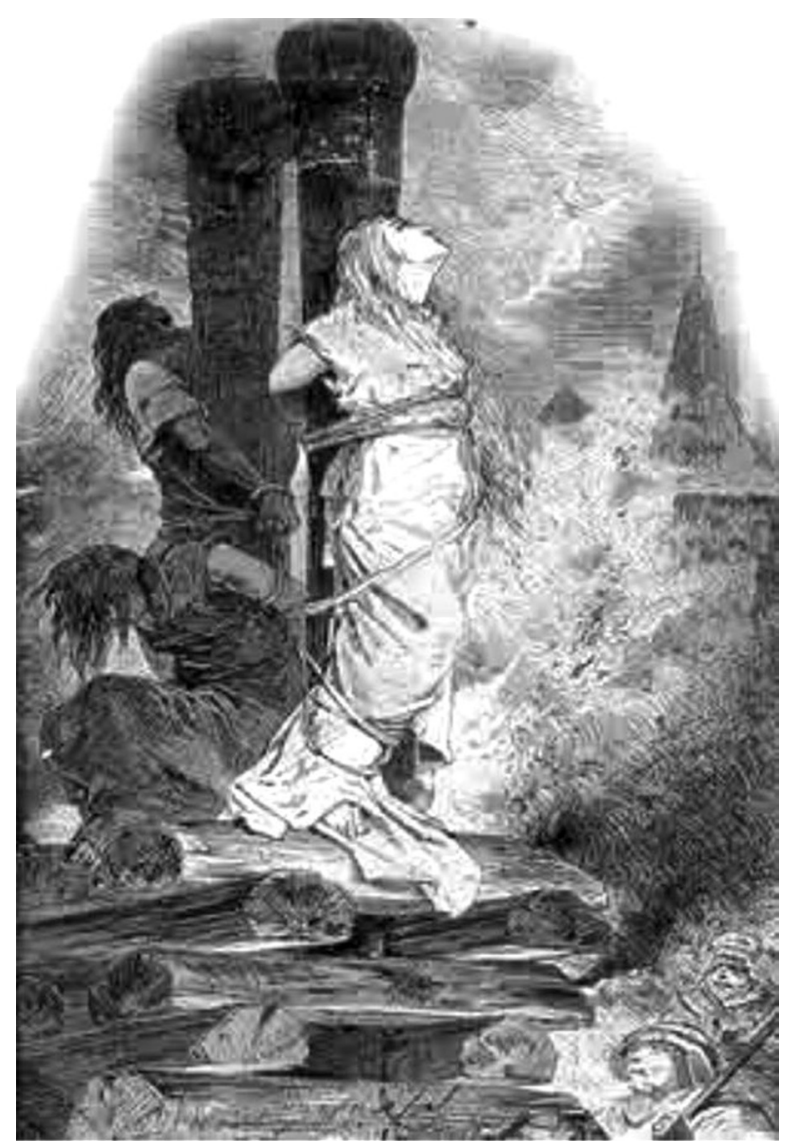

Fig. 2. The fear of witchcraft and possession was so great that hundreds of innocent people were burnt at the stake (http://www.linkpolonia.com)
However, canonical law still has difficulty tolerating epilepsy. It was only in 1983 that the ban forbidding men with epilepsy to study at Catholic seminaries was lifted and deleted from the Codex Iuris Canonici. As far as marriage between patients with epilepsy is concerned, canon law states that epilepsy may interfere with canonical capacity for marital consent and hence render the marriage invalid from the very start [7]. Catholic jurisprudence therefore steadfastly defends these legal regulations and has maintained its conservative opinions for centuries.

\section{The Orthodox Church}

Metaphysical ideas concerning the nature of epilepsy have been presented again and again in the Orthodox literature and its theological treatises. According to the rules of Orthodox faith, epilepsy is a somatic or spiritual structural deficiency which interferes with complete development and leads to inhibitions at work and study. According to Orthodox luminaries, physical or psychological distress, like poverty and sin, are an integral part of human life. To leave those in distress to their own devices, without adequate help, is cruel and those who remain indifferent to illness or ignore it deserve eternal damnation. God created medicine and doctors so that they can alleviate human suffering. According to the Book of Transfiguration ( $16^{\text {th }}$ century), it is advisable to respect doctors because God has invested them with special powers which they can use to alleviate certain human maladies and sufferings.

As in other religions, the leading Orthodox theologians, St John the Golden Mouth and Blessed August, believed that epilepsy was the natural consequence of original sin [8]. They considered epilepsy to be a mental affliction and explained its aetiology in terms of possession by a demon. The Orthodox authorities believed that someone who was as strong as the healthy and felt no pain could not be ill. From time to time an impure spirit entered such people, preventing them from being themselves. This spirit had but one purpose - to lead to the possessed one's death - and that is why it made its presence felt when the victim was most vulnerable (e.g. was near a fire, at full sea or at a height).

According to Episcop Michael [9], the impure spirit which evokes epileptic seizures is a demon who is continually out to kill somebody. He interprets the dynamics of the epileptic attack according to the canons of his faith: 'The demon which enters the sick man, and shakes his body, when he seems not to be alive, is the worst type of 
demon. It is stronger than the one which throws the sick man's body around and commands him to shout, but it does not deprive him of his conscious mind completely' [9]. The natural world is full of demons of all kinds. They are capable of committing evil deeds and tormenting people in various ways and it is they that are responsible for minor and major misfortunes. St John the Golden Mouth (12 ${ }^{\text {th }}$ century) thought that Satan was the demon responsible for epilepsy. Satan was a former angel who rebelled and was the first fallen angel to be expelled from heaven by God. This was the most dangerous kind of demon. That is why epilepsy often gets worse. Initially, although the demon is in possession of the sick man's body and enters it during seizures, he then leaves it and that is why epileptic people are "normal" between seizures. The longer the sickness lasts, however, the more often the demon plays tricks with the body and the less frequently he leaves it. By entering the human body, the demon deprives people of control of their senses and steals their soul, bit by bit. Most important is his explanation why the apostles were unable to send the impure spirit away when it entered the epileptic patient's body although earlier they had successfully cured blind or paralyzed people. According to experts in Orthodox literature, the demon who enters the epileptic patient's body is a pure specimen of Satan himself, not one of his servants. That is why only Jesus can heal the epileptic person. Only Jesus has sufficient power to order the demon to leave the possessed person's body, never to return. But even having listened to Christ's commands, the impure spirit tries to show who is in charge once again and shakes the patient's body [8].

Orthodox scriptures contain precise regulations concerning prayers for very seriously ill people, including the mentally ill and people with epilepsy. The ceremony is called Anointment with the Holy Oils. Seven priests participate and they read seven fragments of the Gospel, then seven fragments of the History of the Apostles, and finally seven prayers for grace and health during which special oils are blessed and the patient is anointed.

In the Orthodox rite, doctors can try to heal people who have seizures. This is an extremely tedious and difficult procedure, however. The doctor is advised to fast for 40 days (drinking only small amounts of water, just enough to survive) and to say special prayers. Both the doctor and the patient must adhere to these restrictions.

Despite the generally tolerant attitude of Orthodox believers toward patients with epilepsy, the gates of the monasteries have been closed for time immemorial for young epileptic men who would like to become priests.

\section{The Reformation}

The metaphysical aspects of epilepsy are also reflected in Protestant literature, just as they are in other religious and cultural literatures. The reflections of two leading Protestant dogmatists, Martin Luther and John Calvin, had a major impact on Protestant beliefs concerning the nature of epilepsy. In his interpretation of the Gospel of St Matthew describing the healing of a young epileptic boy, Calvin reflects on the risks which this disease carries. He suggests that Satan takes advantage of every opportunity to get hold of a person's soul and does so very slyly when the person concerned is weak or ill. He believed that epilepsy was caused by organic brain damage and hence the typical weakness of the nervous system (debilitas cerebri et nervorum). But were it not for the fact that Satan acts with God's permission, the disease would wreak even more havoc. The visible and obvious but not life-threatening symptoms of permanent harm caused by epilepsy include, according to Calvin, sadness, a sense of restriction and abandonment, and loss of social position [10].

According to Martin Luther's reformatory ideas, the eternal struggle between God and Satan for the human soul is the reason why people are confronted with dangerous and dramatic situations such as severe illness. Luther's term for epilepsy was morbus comitialis, and what interested him most was the state of the soul of the epileptic patient during a seizure. Luther did not think that epilepsy was caused by possession by demons. On the contrary, he pointed out that epilepsy had certain positive aspects. He believed that the epileptic attack was a form of sleep (figment humana) which allowed the patient to get a glimpse of God's secrets and to gain insight into the very nature of faith. Here is a quotation which illustrates this opinion: '...We are so accustomed to our everyday slumber that we even often call death sleep. In a way, sleep is an escape from life; ... But seeing that sleep is an everyday and vital situation, nobody runs away from it, nobody is afraid of it as opposed to the disease called epilepsy, the mention of which makes many a man panic. During an epileptic attack patients lose their senses, enter a different kind of being, as if they were burning in fire or drowning, they do not feel reality, they neither hear, nor see, yet they are still alive, although they look as if they were dead (epileptic viventes mortus sunt). This is also how children sleep in their mother's womb, yet no one is able to understand this miracle or express it with words. We know nothing except that sleep is indispensible and has a healing effect' [10]. 
During the Enlightenment, Protestant theology adopted common-sense methods of explaining Gospel phenomena. Satan with his fatal and detrimental effects on the human soul was now believed to be a product of the human imagination of people of bygone days. The theological truths of the age of Enlightenment condemned the belief in demons and impure spirits and all that was associated with them. Johan Salomo Selmer wrote a treatise in which he strove to demonstrate the irrationality of belief in the destructive agency of Satan. Those sick people who were mentioned in the Gospels as possessed by the devil were ordinary, poor people whose behaviour had been erroneously interpreted by society.

\section{Myths and reality}

For years people have been trying to explain various phenomena intuitively. They attribute those phenomena they are unable to explain to supernatural forces (the gods, evil forces, demons, etc.). The accepted version is not always true or supported by empirical evidence. That is how myths and superstitions develop. Every society has many fantastic beliefs concerning various phenomena, including diseases. Many of them apply to epilepsy and people afflicted with it. There are many misunderstandings concerning the nature of the disease. Many people believe that epilepsy is a rare disease or, worse still, they equate it with mental diseases. Epilepsy is also sometimes thought to be contagious, congenital and incurable [11]. It is also commonly believed that patients with epilepsy should not have stressful and responsible jobs [12]. Some people are convinced that patients with epilepsy look 'queer' or, worse still, 'disgusting' [13]. A considerable portion of society is also convinced that people with epilepsy 'tend to attack other people and are a threat to society'. There are also many myths concerning epileptic seizures [14]. The majority of people think that all seizures are the same. Epileptic seizures are usually associated with dramatic tonic-clonic convulsions. One frequent misunderstanding is that if we want to help a patient who is having an attack we must put a metal object in his/her mouth, e.g. a spoon, and then immobilize the patient. Another frequent misunderstanding is the belief that patients might swallow their tongues during an attack [15]. Things have gradually changed for the better but, as we know from everyday practice, many of these myths and misunderstandings about epilepsy persist and per- petuate the "false" image of epilepsy itself and the patient with epilepsy. Many of these myths continue to function in the patient's social environment, sometimes even in the family. What is more, patients themselves believe in some of these myths and this belief aggravates their fear, their tendency to conceal their condition, their lack of self-confidence, or their fear of the future. All this has a negative effect on their treatment, acceptance of their disease, and their quality of life. Patients with epilepsy have to bear the consequences of their illness in the form of stigma. This stigma is rooted in centuries-old myths, false beliefs and misunderstandings.

\section{Conclusions}

The ideas presented in religious writings are very ancient ideas. They are full of mysticism and error and have caused people with epilepsy much anxiety and harm. Many people believed that epilepsy was a sacred disease whereas others were convinced that it was a sign of possession by the devil or impure spirits. Various superstitions and false theories concerning epilepsy developed within different religions all over the world. Many myths and superstitions have survived to this day. Nowadays it is still quite common to view people with epilepsy as having mystical and supernatural powers. We can find many bizarre methods of treatment of epilepsy in the history of medicine [1]. These methods were believed to have a mysterious potency. Some of them are now forgotten, while others have survived to this day and still continue to leave their mark in the form of intolerance of people who suffer from epilepsy. This lack of acceptance and tolerance is largely the product of ignorance. Societies still differ greatly as far as their knowledge of epilepsy and correct treatment of patients with epilepsy are concerned. Many people still do not know how to help someone who is having an epileptic attack. During attacks patients often lose control of their bodies, minds and emotions. Like the sword of Damocles, epileptic seizures take people by surprise. They are unpredictable and the patient knows neither when nor where they will occur. The disease itself is not obvious and cannot be seen apart from the attacks. This undermines the social need of coherence and predictability.

Within the last hundred years our knowledge of epilepsy and its psychosocial consequences has greatly increased. The most rapid progress as far as diagnosis and treatment are concerned has taken place in the last forty years. Although we know more and more about 
epilepsy and attitudes are changing for the better, information concerning the potential for good functioning in patients with epilepsy is still insufficiently disseminated and accessible.

\section{Disclosure}

Authors report no conflict of interest.

\section{References}

1. Owczarek K. Treating epilepsy: A review of Polish historical sources. Epilepsy Behav 2011; 6: 123-138.

2. Wolf P. Sociocultural history of epilepsy. In: Panayiotopoulos C.P. [ed.]. Atlas of Epilepsies. Springer-Verlag Limited, London 2010, pp. 128-6.

3. Baker G.A., Brooks J., Buck D. The stigma: a European perspective. Epilepsia 1999; 41: 98-10.

4. Siemianowski C. Epilepsy in the Old and New Testament. Epileptologia 1998; 6: 35-39.

5. The Bible, New International version. 1973; http://www.biblegway.com.

6. Sprenger J., Instytor H. Acts of witchcraft, and how to protect oneself against them, and remedies, all encompassed in two parts. Kempini, Kraków 1614.

7. Graczyk K. Epilepsy and its effect on canonical capacity for marital consent in light of the doctrine of the Catholic church. Epileptologia 2000; 8: 115-126.

8. Grabowska-Grzyb A., Iwanow I.S., Iwanowa M.I. Epilepsy in orthodox literature and scriptures. Epileptologia 1999; 7: 257-267.

9. Episcop M. Explaining the Gospel. Bot, Sofia 1880.

10. Schwager H.J. Epilepsy in Luther's Works and protestant church theology. Epileptologia 1997; 5: 325-331.

11. Owczarek K., Rozenek H. Psychosocial aspects of epilepsy. Acta Neuropsych 2010; 3: 65-77.

12. Aldenkamp A.P., Van Donselaar C.A., Flamman H., et al. Psychological reactions to epilepsy in an unselected group of patients with epilepsy under treatment in general hospitals. Seizure 2003; 12: 101-106

13. Jacoby A. Felt versus enacted stigma: a concept revised. $S o c S c i$ Med 1994; 38: 266-274.

14. Jacoby A. Stigma, epilepsy and quality of life. Epilepsy Behav 2002; 3: 10-20.

15. Kapinos M., Łabuz-Roszak B., Pierzchała K., et al. Assessment of knowledge and attitudes toward epilepsy in university students - a survey. Ann Acad Med Siles 2006; 60: 302-313. 